\title{
Population structure and reproductive status of the invasive Eriocheir sinensis (Decapoda, Varunidae) in the Tagus estuary (Portugal)
}

\author{
Pedro M. Anastácio ${ }^{1, *}$, Mónica Marques ${ }^{1}$, Maria Águas ${ }^{1}$, Dagmara Wójcik-Fudalewska² and \\ Monika Normant-Saremba ${ }^{2}$
}

${ }^{1}$ MARE - Marine and Environmental Sciences Centre. Department of Landscape, Environment and Planning, School of Sciences and Technology, University of Évora, Rua Romão Ramalho 59, 7000-671 Évora, Portugal.

2 Department of Experimental Ecology of Marine Organisms, Institute of Oceanography, University of Gdańsk, Al. Marszałka J. Piłsudskiego 46, 81-378 Gdynia, Poland.

* Corresponding author: anast@uevora.pt

Received: 20/02/16 Accepted: 20/07/17

\begin{abstract}
Population structure and reproductive status of the invasive Eriocheir sinensis (Decapoda, Varunidae) in the Tagus estuary (Portugal)

The Chinese mitten crab (Eriocheir sinensis, Milne Edwards, 1853) is a highly invasive catadromous species established in the Tagus river. Since there is insufficient data about the species in this invaded area, the aim of this study was to characterize its population structure and reproductive dynamics. This population is at a much lower latitude than most other well studied European E. sinensis populations, therefore strong differences should be expected, possibly affecting the choice of management strategies. E. sinensis bycatch was obtained in the upper Estuary using fyke nets on an approximately monthly basis from September 2013 to October 2014. Population structure, female gonad development, fertility, condition and growth were analyzed. An overall sex ratio of $1.54(\mathrm{M} / \mathrm{F})$ was found, but it oscillated significantly along the year. Ovigerous females were found from March to May, mostly during a period of low flow and high salinity (3-7 PSU). The average number of eggs per female was 36350 , which is low when compared with other areas where the species is established. Loss of appendages was observed in $44.4 \%$ of the crabs, potentially affecting its commercial use. In conclusion, this well-established short lived population, presents an unusually low fertility which may explain why there have been no remarkable population explosions. To decrease the risk of larvae transport by ballast water from the Tagus to other nearby estuaries seasonal control measures could be applied from April to July.
\end{abstract}

Key words: population dynamics, growth, sex ratio; fertility, Chinese mitten crab

\section{RESUMO}

Estrutura populacional e estado reprodutor da espécie invasora Eriocheir sinensis (Decapoda, Varunidae) no estuário do Tejo (Portugal)

O caranguejo-peludo-chinês (Eriocheir sinensis, Milne Edwards, 1853) é uma espécie catádroma, altamente invasiva, que se estabeleceu no rio Tejo. Devido à insuficiência de dados sobre a espécie nesta área, o objetivo deste estudo foi caracterizar a estrutura da população e a sua dinâmica reprodutora. Esta população encontra-se a uma latitude muito menor do que a maioria das populações europeias bem estudadas. Por este motivo são expectáveis diferenças significativas, que poderão afetar a escolha de estratégias de gestão da espécie. De setembro de 2013 a outubro de 2014 obtiveram-se, com periodicidade aproximadamente mensal, exemplares de E. sinensis provenientes de capturas acessórias com nassas na parte superior do estuário. Foi analizada a estrutura populacional, o desenvolvimento das gónadas das fêmeas, a fertilidade, a condição corporal e o crescimento. O rácio sexual médio foi de $1.54(\mathrm{M} / \mathrm{F})$, embora tenha oscilado fortemente durante o ano. Foram detetadas fêmeas ovígeras de março a maio, principalmente durante um período de baixo caudal e salinidade elevada (3-7 PSU). Cada fêmea ovígera apresentou em média 36350 ovos, sendo este um número reduzido quando comparado com outras áreas do globo em que a espécie se estabeleceu. Observou-se perda de apêndices em $44.4 \%$ dos indivíduos, facto que poderá prejudicar 
o seu aproveitamento comercial. Em conclusão, esta população bem estabelecida e com indivíduos de vida curta, apresenta uma fertilidade invulgarmente baixa que poderá explicar a ausência de explosões populacionais. Para impedir a propagação de larvas da espécie para outros estuários, sugere-se a aplicação de medidas de controle de águas de lastro de embarcações durante os meses de abril a julho.

Palavras chave: dinâmica de populações, crescimento, proporção de machos; fertilidade, caranguejo-peludo-chinês

\section{INTRODUCTION}

The Chinese mitten crab (Eriocheir sinensis, Milne Edwards, 1853) is a highly invasive catadromous species (Lowe et al., 2000). This brachyuran crab can be distinguished from other European species by a square-shaped carapace, usually with 5-7 cm width and by its hair-like structures covering the claws, especially in males. In Europe, it is one of the invasive alien species of concern under the latest European Union's Regulation on the prevention and management of the introduction and spread of invasive alien species (EU, 2014; go.nature.com/gigftz). Adults mate and spawn in the estuaries, the juveniles migrate up the rivers and adults migrate back to estuaries to complete the life-cycle and die (Veilleux \& De Lafontaine, 2007; Dittel \& Epifanio, 2009). This species is native from Eastern Asia and has currently a wide invasive distribution throughout the globe, especially in Europe, North America and Western Asia (Dittel \& Epifanio, 2009; Capinha et al., 2011). The first European record was in 1912 in the Aller river in Germany (Kamps, 1937; Panning, 1938). In the Tagus river (in Portugal), E. sinensis was noticed for the first time by local fishermen in the late 1980's (Cabral \& Costa, 1999). Therefore, it may be assumed that the time of residence of this species in the Tagus river may be more than 30 years, making it a well-established population. In spite of this long period, this is one of the most recent well established European populations of this species. It is characterized by lower allelic richness when compared to other older European populations and seems to be genetically closer to northern European populations than to the populations found in the UK or in its native range (Herborg et al., 2007b).

It is well known that there are differences in population ecology among the numerous intro- duction areas of E. sinensis (Rudnick et al., 2005). Although this species may pose significant threats to freshwater and marine ecosystems as well as to the economy (e.g. impacts on fisheries and loss of river bank stability; see for example: Rudnick et al., 2000; Veilleux \& De Lafontaine, 2007; Dittel \& Epifanio, 2009), the local population from the Tagus estuary has not yet been thoroughly studied. Previous data are clearly insufficient and include a note on the first occurrence of the species with some information about the individuals caught (Cabral \& Costa, 1999), a short paper characterizing the animals caught during September in a single year (Wójcik et al., 2014) and a survey about the fishermen's perception of the species (Coelho, 2014). The latter study identified some commercial capture of the species in the Tagus river and complaints about damages to the fishing nets and to the fish. $E$. sinensis individuals can be found as far upstream as the Belver dam wall (Coelho, 2014) located ca. $140 \mathrm{~km}$ away from the mouth of the estuary, and there are some fishermen's reports of sporadic increases of crab density. These occurrences are consistent with the species typical pattern of migrations in which juveniles migrate upstream and adults return to the estuary to reproduce in more saline waters. In spite of this, so far there has not been a perceived presence in such large numbers as in other invaded areas. The absence of very large densities may be one of the reasons for the limited use of the species as a fisheries resource as opposed to Germany (Fladung, 2000) or to its native range where it is considered a luxury food item (Sui et al., 2011).

The history of $E$. sinensis invasion is quite different among European sites. For example, in Germany, very high densities were attained in the first years after the invasion (Panning, 1938), while in the UK it took a long period before large densities were perceived (Clark et al., 1998). 
Large population fluctuations are very common in this species (e.g. Fladung, 2000) and there is no reason to suppose that this cannot also occur in the Tagus estuary. Moreover, the frequency of recent invasion events of this species throughout the world (e.g. Robbins et al., 2006; De Lafontaine et al., 2008; Drotz et al., 2010; Garcia-de-Lomas et al., 2010; Pezy et al., 2015), also indicate that there is a potential risk of expanding $E$. sinensis invasion to other regions. Several studies have shown that many areas in the Iberian Peninsula (Capinha \& Anastácio, 2011; Capinha et al., 2012), in the rest of Europe (Herborg et al., 2007a) and also throughout the world (Capinha et al., 2011) present suitable conditions for the invasion by this species. Therefore, it is important to know the Tagus population ecology before planning any management, exploitation or prevention measures. The aim of this study was to characterize the $E$. sinensis found in the upper Tagus Estuary. Keeping in mind that this estuary is located at a much lower latitude and therefore a much warmer area than most other well studied European E. sinensis populations (e.g. river Elbe in Germany), strong differences should be expected.

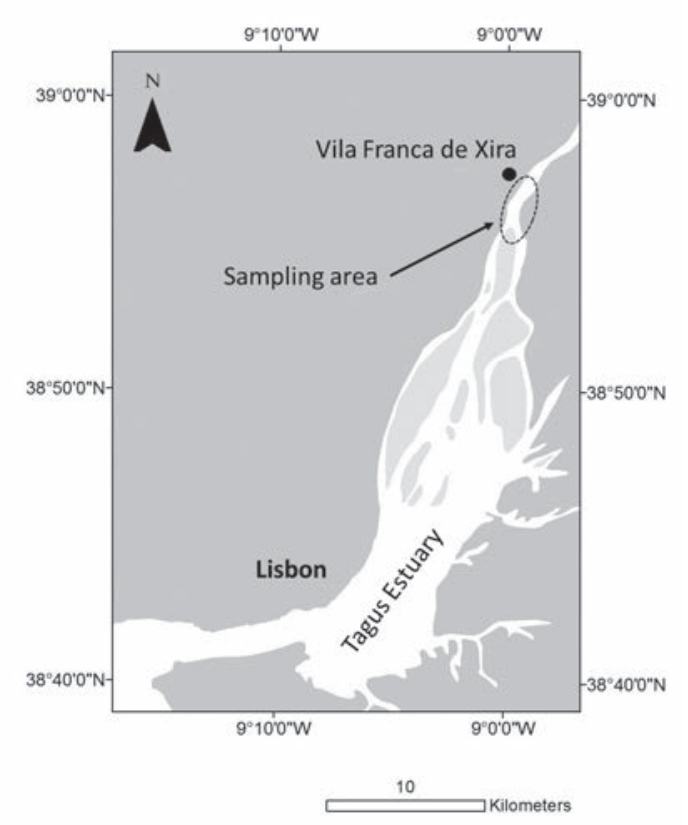

Figure 1. Location of the sampling area in the upper Tagus estuary, Portugal. Localização da área de amostragem no topo do estuário do Tejo, Portugal.

\section{MATERIALS AND METHODS}

\section{Study site}

The Tagus river is the longest in the Iberian Peninsula $(1070 \mathrm{~km})$. Its estuary is one of the largest of western Europe $\left(325 \mathrm{~km}^{2}\right)$ and one of the 10 most important wetlands for water birds in Europe (Dias \& Marques, 1999). The climate of the area is Mediterranean, with a precipitation range from $600-700 \mathrm{~mm} /$ year and mean air temperatures between 16 and $17.5{ }^{\circ} \mathrm{C}$. Four different sections can be considered in this estuary, from its top (upstream) to its mouth. The study site was in the upstream section, which has a delta type structure and a depth of less than $5 \mathrm{~m}$ (Fig. 1). This section includes the majority of the Tagus Estuary natural preservation area. It possesses a great biodiversity and constitutes the main nursery area of the estuary. Although tidal influence is observed up to $80 \mathrm{~km}$ upstream of the mouth, saline intrusion only reaches the top of this estuarine section, i.e. approximately $50 \mathrm{~km}$ upstream of the mouth, at the town of Vila Franca de Xira.

\section{Methods}

Eriocheir sinensis bycatch was obtained in the upper Tagus Estuary, mostly downstream of Vila Franca de Xira's bridge over the Tagus, Portugal (Fig. 1), from local fishermen using fyke nets (mesh: $\varnothing=20 \mathrm{~mm}$ ) randomly placed near the shoreline (ca. 3 to $15 \mathrm{~m}$ ). The site was selected for its large fishermen community and the consistency in the capture of $E$. sinensis adults throughout the year. A random taken sample of the bycatch, weighing 2 to $4 \mathrm{~kg}$, was acquired on an approximately monthly basis from September 2013 to October 2014 and animals were separately frozen $\left(-20{ }^{\circ} \mathrm{C}\right)$. After defrosting, crabs were sexed on the basis of their abdominal structure (Schäferna, 1935). The carapace width of each individual was measured $( \pm 0.01 \mathrm{~mm})$, and the wet weight of specimens was determined $( \pm 0.01 \mathrm{~g})$. Additionally, female gonads were extracted and examined in regard to the five-scale gonad maturity stages described by Garcia-de-Lomas et al. (2010). For each ovigerous female the total egg mass was 


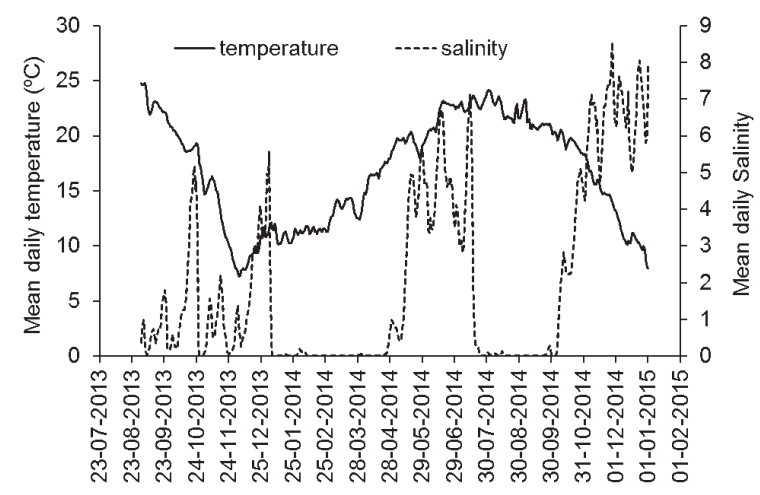

Figure 2. Mean daily values of the water temperature and salinity in the sampling area. Valores médios diários da temperatura da água e da salinidade na área de amostragem.

obtained $( \pm 0.0001 \mathrm{~g})$ and then 3 random samples of each egg mass were weighed and counted separately under the stereomicroscope. This allowed to estimate the total number of eggs per female. Regressions between number of eggs per female and wet weight or carapace width were calculated and its statistical significance was assessed (alpha set at 0.05).

Continuous data for environmental variables such as water temperature and salinity in the sampling area was obtained from the MOHID platform (http://forecast.maretec.org) (Franz et al., 2014). These variables were selected due to their well-known importance to crustacean biology, namely to its reproductive processes. Tagus river discharge data was obtained online (http://snirh.apambiente.pt, SNIRH, 2015) from the nearest point downstream of all major Tagus river tributaries and dams (Almourol, $39^{\circ} 27^{\prime} 42^{\prime}$ 'N, $8^{\circ} 22^{\prime} 55^{\prime}$ 'W). Discharge may be an important proxy for seasonal changes in estuarine salinity.

Crabs were divided into $5 \mathrm{~mm}$ width size classes, starting at $10 \mathrm{~mm}$ and size-frequency histograms $(\mathrm{mm})$ of the population were constructed. We used the FISAT II software (version 1.2.2, FAO-ICLARM) and applied modal progression analysis to size-frequency distribution data. Normsep's method with the Simplex algorithm was used, after an initial analysis with the Bhattacharya method (Sparre et al., 1992). For each cohort identified by
Normsep's method, the mean carapace width (CW) and the standard deviation (SD) were calculated. Additionally, growth parameters for the most complete cohort growth data set (first male cohort - mcl) were estimated using the same computer program. Asymptotic length $\left(\mathrm{L}_{\infty}\right)$ of males was estimated by the Maximum Length Estimation method and a non-oscillating von Bertalanffy growth function (VBGF) (Bertalanffy, 1957) was fitted to mc1 using Munro's method with a fixed $\mathrm{L}_{\infty}$ (Munro, 1982). The equation for VBGF is $\mathrm{L}(\mathrm{t})=\mathrm{L}_{\infty}\left[1-\exp \left(-\mathrm{K}\left(\mathrm{t}-\mathrm{t}_{0}\right)\right)\right]$, where $\mathrm{L}(\mathrm{t})$ is the crab's carapace width $(\mathrm{CW})$ at time $t ; \mathrm{L}$ $\infty$ is the theoretical maximum CL of the crab; $\mathrm{K}$ is the curvature parameter which records the rate at which the $\mathrm{L}_{\infty}$ is obtained; and $\mathrm{t}_{0}$ is a theoretical value for time when the CL is equal to 0 .

The condition of the crabs was calculated only for complete individuals (not missing appendages) using Fulton's condition index $(\mathrm{K})$, with the formula: $\mathrm{K}=\mathrm{W} / \mathrm{L}^{3}$, where $\mathrm{W}$ - wet weight (g); $\mathrm{L}$ carapace width (mm) (Ricker, 1975). Additional statistical analyses were conducted with SPSS 20. Chi-square tests on contingency tables were used for the assessment of whether sex ratio depended on the month and whether the proportion of appendages lost was affected by sex. Spearman rank correlations were calculated among biological features (sex ratio, female's Fulton, male's Fulton, $\% \mathrm{G} 5$ females in the sample) and each environmental variable (salinity, temperature, flow).

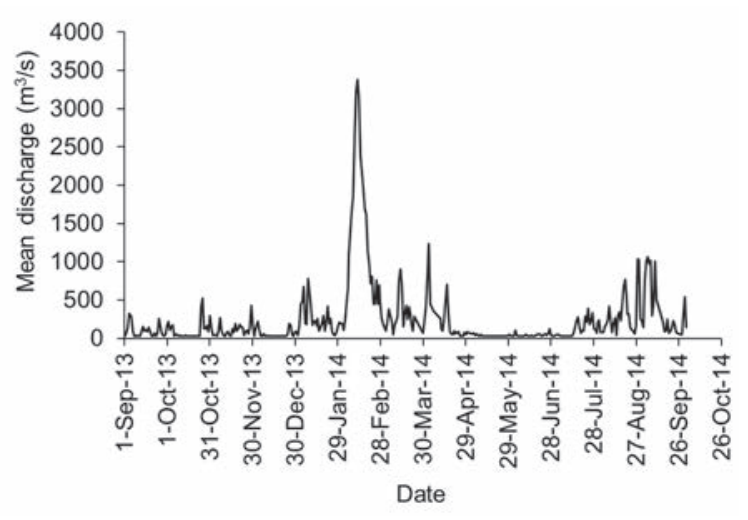

Figure 3. Mean discharge of the river Tagus from the nearest available upstream station, in Almourol (http://snirh.apambiente.pt, SNIRH 2015). Descarga média do rio Tejo medida na estação mais próxima a montante, em Almourol (http://snirh.apambiente.pt, SNIRH 2015). 


\section{RESULTS}

The lowest average daily water temperatures occurred in early December 2013 and the maximum temperatures occurred in early August 2014 (Fig. 2). January to April 2014 was characterized by large freshwater inflow and very low salinity and the same occurred from mid-July to the end of September (Fig. 2). The period of largest discharge was from January to April, with maximum values in February. However, August and September also had large discharges (Fig. 3). A total of 1068 animals were analyzed but during the months of June and September 2014 there was no bycatch of crabs by local fishermen.

Of the total number of crabs caught, 648 were males and 420 were females, corresponding to an overall sex ratio of 1.54. However, sex ratio was extremely variable along the year (Fig. 4) and almost no females were captured from January to April (Fig. 5). Sex ratio and month were significantly associated (Chi-square $=152.329$, d.f. $=8$, $p<0.001)$. The highest proportions of males in the population occurred during the cold months, at high flow and low salinity and the maximum sex ratio was 27, during March 2014. However, sex ratio was only significantly correlated with flow (spearman Rank correlation coefficient $=0.828$, $p=0.006$ ).

The smallest $E$. sinensis specimens were captured in the summer and the smallest one had $11.64 \mathrm{~mm}$ of carapace width. Animals were larger

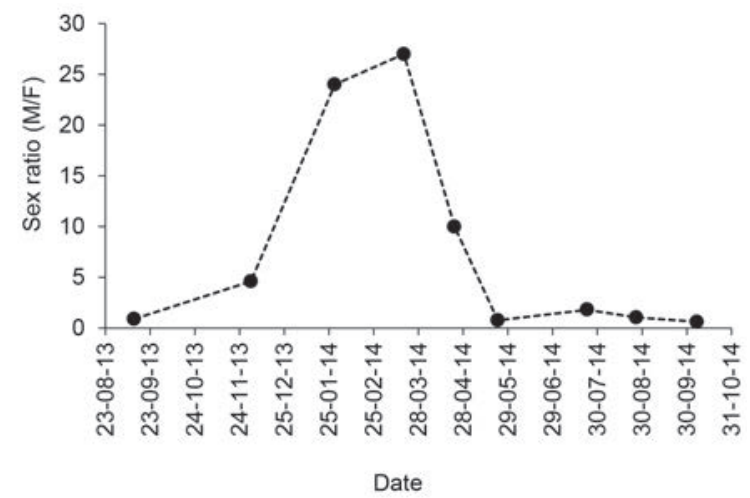

Figure 4. Sex ratio (M/F) of Eriocheir sinensis population in the upper Tagus estuary throughout the year of 2013/2014. Rácio sexual (M/F) da população de Eriocheir sinensis na parte superior do estuário do Tejo, durante o período de 2013/2014. between December and May and the largest animals of each sex were a male with $75.86 \mathrm{~mm}$ and a female with $69.74 \mathrm{~mm}$ of carapace width. These were also the heaviest male and female, with $214.5 \mathrm{~g}$ and $138.0 \mathrm{~g}$ wet weight, respectively. Larger males and females co-occurred in December and May. The best mean values of body condition (Fulton index) were observed in December and in January (Fig. 6). When compared with females, males consistently presented higher mean values of the Fulton index throughout the year. However, no statistical comparisons were performed since the size of the animals also suffered large variations and this could affect the Fulton index values. No significant correlations were found between male or female condition and environmental variables (temperature, salinity or flow).

Ovigerous females (stage G5) were found from March to May but most of these were captured in May (Fig. 7). No significant correlations were found between the percentage of ovigerous females and environmental variables. A total of 44 females carrying eggs were
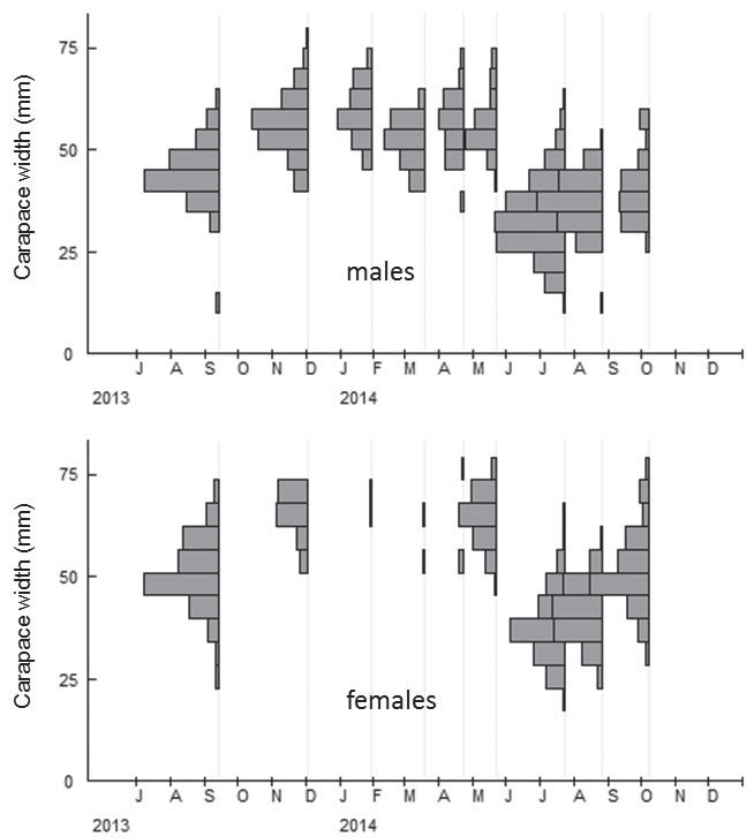

Figure 5. Size class distribution of Eriocheir sinensis males and females, based on carapace width. Distribuição de classes de tamanho de machos e fêmeas de Eriocheir sinensis, com base na largura da carapaça. 


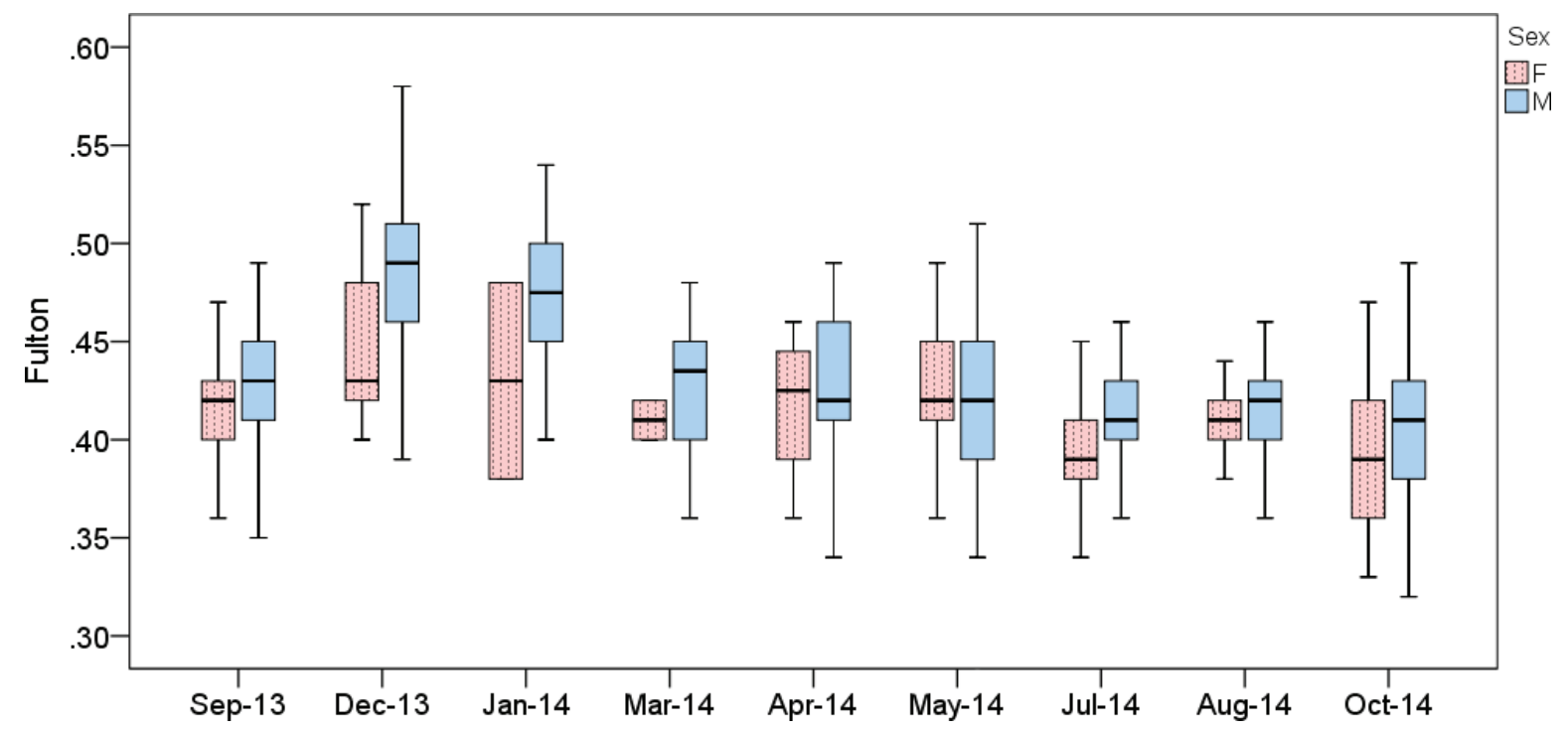

Figure 6. Condition (Fulton index) of Eriocheir sinensis males and females throughout the year of 2013/2014. The box extends from the 25th percentile to the 75th percentile, with horizontal line at the median. Whiskers show the range of the data. Condição (indice de Fulton) dos machos e fêmeas de Eriocheir sinensis durante o período de 2013/2014. A caixa estende-se do percentil 25 até ao percentil 75, com a linha horizontal a representar a mediana. Os bigodes (traços verticais) indicam a amplitude de valores dos dados.

captured, with a mean carapace width of 56.47 $\mathrm{mm}(\mathrm{SD}=5.61)$ and the smallest ovigerous female had a $44.60 \mathrm{~mm}$ carapace width. The maximum estimated number of eggs carried by one female was 120 046, but many ovigerous females, large or small, presented a very low number of eggs. The mean number of eggs carried by ovigerous females was $36350(\mathrm{SD}=25688)$. The number of eggs per female was linearly related to carapace width $\left(y=2031.7 x-78375, r^{2}=0.1968\right)$ and to wet weight $\left(y=591.29 x-10506, r^{2}=0.2679\right)$. Although the coefficients of determination $\left(\mathrm{r}^{2}\right)$ were low, both cases presented statistically significant correlations between the variables.

A new cohort was detected at the end of July (Fig. 5 and 8) but it did not correspond to newly born individuals. Males were $32.56 \mathrm{~mm}( \pm 7.40$ $\mathrm{SD})$ and females were $33.47 \mathrm{~mm}( \pm 6.28 \mathrm{SD})$ in carapace width. Assuming egg hatching in the end of May, i.e. approximately 60 days before the detection of these cohorts, this would indicate an approximate mean growth of $15-16 \mathrm{~mm} / \mathrm{month}$ for males and females if these were born during the study year. If the animals were from the previous year, the mean growth would be of 2.2-2.3 $\mathrm{mm} / \mathrm{month}$. It was only possible to estimate Von Bertalanffy Growth Curve (VBGC) parameters for the males because of insufficient number of females (they were almost absent for a part of the year). VBGC parameters for the males were $\mathrm{L}_{\infty}$ $=64.52$ and $\mathrm{k}=1$. These values should be used with caution because there was no data for very small crabs.

Loss of appendages was observed in $44.4 \%$ of the total number of crabs, with $41 \%$ presenting leg loss and $5.9 \%$ presenting chelae loss. Some individuals presented simultaneous loss of both types of appendages. The most frequent situation was the loss of one single appendage but one individual was found without any appendages, probably lost inside the trap. As can be seen in figure 9, there is a decrease in crab frequency as the number of lost appendages increases. The percentage of females with missing or damaged appendages was $39.3 \%$ and the percentage of males with missing appendages was $47.7 \%$. These proportions differed significantly (Pearson Chi-square $=6.947$, d.f. $=1, p=0.008$ ). The proportion of leg loss was associated with sex (Pearson Chi-square $=5.109$, d.f. $=1, p=0.024)$, with loss of legs being slightly more frequent in males (43.8 $\%)$ than in females $(36.7 \%)$. However, the proportion of chelae loss was not associated with sex (Pearson Chi-square $=2.673$, d.f. $=1, p=0.102$ ). 


\section{DISCUSSION}

Our study is one of the few European studies analyzing an E. sinensis population throughout the year and it highlighted distinctive characteristics of $E$. sinensis life-cycle in the Tagus estuary, namely its low fertility and highly male biased sex ratio, while filling important gaps in the previous knowledge of the species invaded range. Most populations of this species present sex ratios of approximately 1:1, or with slight bias towards one of the genders (Rudnick et al., 2000; Zhang et al., 2001; Rudnick et al., 2003; Ojaveer et al., 2007), and male predominance throughout the year (e.g. Ojaveer et al., 2007; Morritt et al., 2013) is not frequent. Fluctuations of the sex ratio are common in other populations of this species (Rudnick et al., 2000; Rudnick et al., 2003; Czerniejewski \& Wawrzyniak, 2006). In the Tagus, the large oscillations in sex ratio were mostly a product of variations in female, rather than male abundance, indicating that females were more mobile than males, changing position depending on their reproductive status.

Our sampling area was located in the upper estuary, where in spite of considerable salinity variations, most times it is a freshwater system. Since hatching and larvae development depend on high salinity (optimum at 20 PSU but affected by temperature) (Panning, 1938; Anger, 1990; Anger, 1991; Montú et al., 1996; Dittel \& Epifanio, 2009), this may be one of the reasons for the very low number of females in most of our samples. Although the sex ratio of our samples was only significantly correlated to flow, in estuaries, salinity is commonly affected by the incoming freshwater flow (e.g. Copeland, 1966; Rudek et al., 1991) and this may explain why females were present in the higher estuary during periods of low flow. In fact, the values for salinity were daily means in a tidal influence area and this may mask the dependence of female captures upon salinity.

Some authors have reported that the 'cement-like' substance that attaches the eggs to the pleopods does not harden at low salinities (Peters, 1933; Panning, 1938) but we found females with extruded eggs especially during May. In the coastal Baltic waters (Poland),

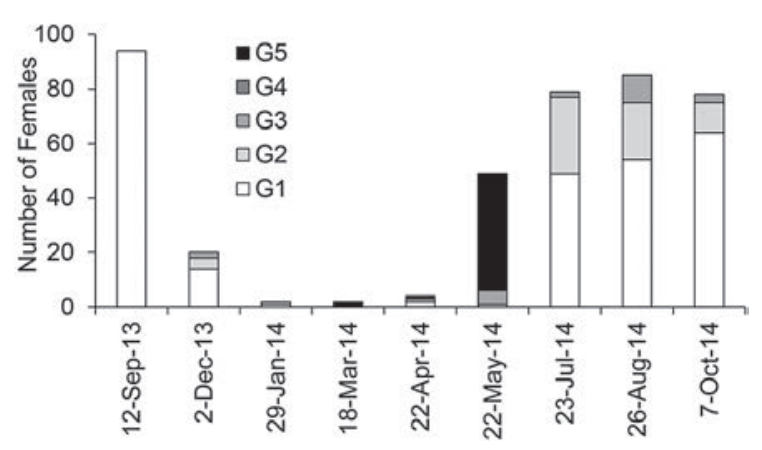

Figure 7. Female reproductive condition based on the analysis of the gonads and eggs. Darker colors correspond to later stages of development. Condição reprodutiva das fêmeas, obtida com base na análise de gónadas e ovos. Cores mais escuras indicam estádios mais avançados de desenvolvimento.

egg-carrying females were also found at a low salinity of 7 PSU (Wójcik \& Normant, 2014), which is a similar value to what was recorded in the Tagus. Reproduction at low salinity conditions (14 PSU, near Kiel Canal, Germany) was also confirmed in other Baltic Sea populations (Otto \& Brandis, 2011) and in China aquaculture mitten crabs with mature gonads are harvested from freshwater environments (Hymanson et al., 1999). Nonetheless, in the Tagus, it is likely that egg laying occurred at higher salinities and females then moved to the upper estuary. Since the egg cluster can be brood for 1-2 months and egg development can be delayed until favorable environmental conditions are found (Rudnick et al., 2005), there would be plenty of time for the females in the Tagus estuary to move among areas with different salinities.

Our study provided for the first time information regarding the reproduction season of the species in the Tagus. In European waters reproductive migration takes place in August-November (peak in September), reproduction in October-January and upstream migration of juveniles is in March-July (for a worldwide review see e.g. Dittel \& Epifanio, 2009). Variations in temperature may however cause adjustments on the dates. It can be that the whole cycle is somewhat delayed in the Tagus, since there are numerous ovigerous females in May, which is a bit later than reported for most European populations. Decreasing temperatures may be one of the 


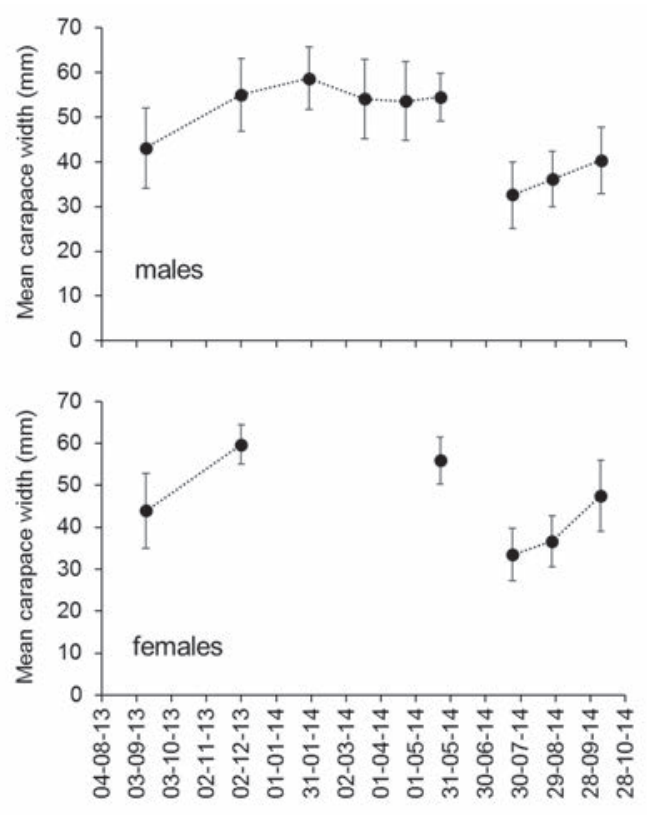

Figure 8. Eriocheir sinensis male and female cohorts identified in the study area. Coortes masculinas e femininas de Eriocheir sinensis identificadas na área de estudo.

factors stimulating gonad development (Rudnick et al., 2005), and this decrease is observed later in the season in the Tagus than, for example, in German waters. May was a month with a very low water flow, allowing salt-water to reach the upper part of the estuary (Fig. 3). It is important to note that large numbers of ovigerous females only occurred at higher salinity (for an upper estuary) and low flow conditions. Spawning in spring is common in the invasive populations of $E$. sinensis, but not in the native populations (Dittel \& Epifanio, 2009), since it also occurs in the areas of San Francisco (USA), the Elbe River (Germany), in the Thames River (UK) and probably also in the Netherlands (Fladung in Bouma \& Soes, 2010). In most of these areas spawning is a bit late in the season and this may be due to differences in temperature regimes. Temperature effects on this animal's life cycle and development have been previously described (Anger, 1991; Rudnick et al., 2000).

E. sinensis can produce 100000 to 1 million eggs (Cohen \& Carlton, 1997; Rudnick et al., 2000). The maximum egg count in the Tagus is low but within this range. Yet, female weight and egg count were significantly related, as in previous studies (e.g. Czerniejewski \& De Giosa, 2013). However, our weak relationship (low $\mathrm{r}^{2}$ ) should be due to other factors affecting egg extrusion or attachment to the crabs. The low salinity where the females were found may affect adherence of the eggs. Additionally, this species reproduces once and then dies (Panning, 1938; Jin et al., 2002), but multiple broods in the reproductive season can occur (Czerniejewski \& De Giosa, 2013). If this is the case, it is possible that some of the females were simply not on their first egg-laying occasion.

In our study, we were able to obtain specimens with a carapace width below the mesh size used $(20 \mathrm{~mm})$. However, no E. sinensis small juveniles (under $11 \mathrm{~mm} \mathrm{CW}$ ) were captured, indicating a low efficiency of the fyke nets for very small specimens, or its absence from the area. Some studies have highlighted the possibility of different spatial distributions of adults and juveniles (Rudnick et al., 2003). It is possible that juveniles only use this section of the estuary as a corridor to move upstream but exclusion of the juveniles from the traps is also likely. This exclusion may be caused by a number of reasons. Juveniles may not be efficiently directed to the trap's entrance, may be vulnerable to predation by large crabs or may simply avoid the largest crabs. Trap

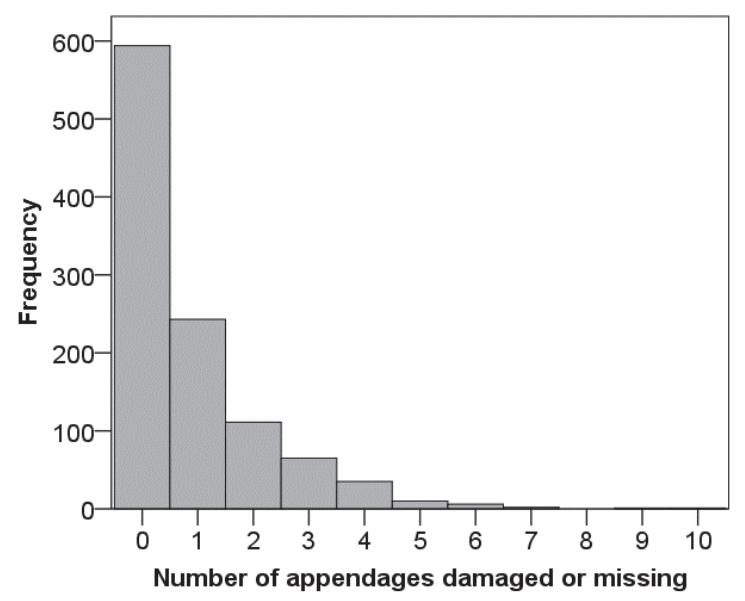

Figure 9. Frequency of occurrence of Eriocheir sinensis individuals with different number of missing or damaged body appendages. Frequência de ocorrência de indivíduos de Eriocheir sinensis com números distintos de apêndices danificados ou em falta. 
selectivity towards size or sex is known for other decapods (e.g. Jeong et al., 2000) and predation of conspecifics is also common in this species (Sui et al., 2011).

In northern European waters maturity occurs after 3-5 years (Dittel \& Epifanio, 2009), whereas in China the life span of the mitten crab is about 24 months (Cohen \& Carlton, 1997). However, some crabs living in Chinese coastal areas can mature in the first autumn (Xu and Li in Jin et al., 2002) and precocious crab populations (i.e. short-lived) have been described (Jin et al., 2001; Jin et al., 2002). This may well be the case with the sampled Tagus population, since no simultaneous detection of 2 cohorts was made, indicating a short life-span. It is known that growth ceases only at temperatures below $7{ }^{\circ} \mathrm{C}$ and above $30{ }^{\circ} \mathrm{C}$ (Rudnick et al., 2000) and therefore in the Tagus area continuous growth is possible. The mild temperature conditions in the area may also contribute for a good condition of the animals during the beginning of the winter. December and January were months in which the individuals presented a high condition factor but also when larger individuals were found in the area. In many areas this is the approximate period for the downstream reproductive migration and it would be appropriate to try to use this resource during this period.

The very high incidence of limb loss (approx. $44 \%$ ) recorded in our study has implications for the potential commercial value of the crab's bycatch. Incomplete animals are less appreciated not only for aesthetical reasons but also because meat from legs is $17.1 \pm 2.4 \%$ of the total crab's weight (Fladung, 2000). In comparison, meat from carapace is on average only $12.3 \pm 1.4 \%$. Additionally, legless crabs weigh a bit less and this corresponds to a loss of income. It is known that decapods in general, may amputate their own claws or lose their legs under stress caused by predators or adverse living conditions. The percentage of limb loss in field populations of decapods varies from 1.7 to $80 \%$ (Mariappan et al., 2000) and E. sinensis, is also known for frequent autotomy (Panning, 1938; He et al., 2016). The fact that loss of chelae was not affected by sex was unexpected, because male $E$. sinensis are usually more aggressive than females
(Rudnick et al., 2000). However, in decapods the frequency of limb loss is usually independent of sex (Juanes \& Smith, 1995). It is impossible to be sure if the crabs in our study lost their appendages before or after they entered the traps but the question is relevant if a commercial exploitation of the species is to be implemented as a means of intensifying the extraction of the species from the river. Improving capture and handling methods may decrease the percentage of limb loss and increase the value of the crab fisheries.

In conclusion, there is a well-established, short lived population of $E$. sinensis in the Tagus river, although with a low fertility. This may explain why so far there have been no large population explosion episodes in this area. Taking into account the history of impacts in other invaded areas and the fact that invader populations can remain low for very long periods before exploding, we recommend a long-term continuous monitoring program for this species. Since there is some variability in the population biology of European populations, management strategies should be site specific. For example, in the Tagus, if control measures are applied to decrease the risk of larvae transport to other nearby estuaries, namely by ballast water, these measures should be most efficient during the period of April to July.

\section{ACKNOWLEDGMENTS}

Data for environmental variables in the sampling area was kindly provided, free of charge, from the MOHID platform by the MARETEC research center team at the Instituto Superior Técnico, University of Lisbon, Portugal. We appreciated particularly the effort in data gathering by Guilherme Franz. The technical assistance in sampling and laboratory analyses of Anna Wojtczak is acknowledged. This research was supported by grant (538-G220-B286-13) from the Faculty of Oceanography and Geography, University of Gdańsk, Poland. The research visit of Ms. D. Wójcik and A. Wojtczak at MARE - Marine and Environmental Sciences Centre, Department of Landscape, Environment and Planning, University of Évora, Portugal was partially funded by Department of Experimental Ecology of Marine Organisms (530-G220-D427-12) and from the 
Faculty of Oceanography and Geography, University of Gdańsk, Poland (530-G000-S901-13, 530-G000-D443-13).

\section{REFERENCES}

ANGER, K. 1990. Der Lebenszyklus der Chinesischen Wollhandkrabbe (Eriocheir sinensis) in Norddeutschland: Gegenwärtiger Stand des Wissens und neue Untersuchungen. Seevögel, 11: 32-36.

ANGER, K. 1991. Effects of temperature and salinity on the larval development of the Chinese mitten crab Eriocheir sinensis (Decapoda: Grapsidae). Marine Ecology Progress Series, 72 (1): 103-110.

BERTALANFFY, L. V. 1957. Quantitative laws in metabolism and growth. The Quarterly Review of Biology, 32(3): 217-231.

BOUMA, S. \& D. SOES. 2010. A risk analysis of the Chinese mitten crab in The Netherlands. Bureau Waardenburg bv, Ministry of Agriculture, Nature and Food Quality, Team Invasive Alien Species, Culemborg, The Netherlands.

CABRAL, H. N. \& M. J. COSTA. 1999. On the occurrence of the chinese mitten crab, Eriocheir sinensis, in Portugal (Decapoda, Brachyura). Crustaceana, 72 (1): 55-58.

CAPINHA, C. \& P. ANASTÁCIO. 2011. Assessing the environmental requirements of invaders using ensembles of distribution models. Diversity and Distributions, 17 (1): 13-24. 10.1111/j.1472-4642.2010.00727.x

CAPINHA, C., P. ANASTÁCIO \& J. A. TENEDÓRIO. 2012. Predicting the impact of climate change on the invasive decapods of the Iberian inland waters: an assessment of reliability. Biological Invasions, 14 (8): 1737-1751. 10.1007/s10530-012-0187-z

CAPINHA, C., B. LEUNG \& P. ANASTÁCIO. 2011. Predicting worldwide invasiveness for four major problematic decapods: an evaluation of using different calibration sets. Ecography, 34 (3): 448-459. 10.1111/j.1600-0587. 2010.06369.x

CLARK, P. F., P. S. RAINBOW, R. S. ROBBINS, B. SMITH, W. E. YEOMANS, M. THOMAS \& G. DOBSON. 1998. The alien Chinese mitten crab, Eriocheir sinensis (Crus- tacea : Decapoda : Brachyura), in the Thames catchment. Journal of the Marine Biological Association of the United Kingdom, 78 (4): 1215-1221.

COELHO, A. F. 2014. Distribuição e abundância da espécie exótica Eriocheir sinensis no estuário do Tejo. MSc Thesis. University of Evora, Évora, Portugal.

COHEN, A. \& J. CARLTON. 1997. Transoceanic transport mechanisms: introduction of the Chinese mitten crab, Eriocheir sinensis, to California. Pacific Science, 58 (1): 1-11.

COPELAND, B. J. 1966. Effects of Decreased River Flow on Estuarine Ecology. Journal (Water Pollution Control Federation), 38 (11): 1831-1839.

CZERNIEJEWSKI, P. \& M. DE GIOSA. 2013. Realized Fecundity in the First Brood and size of Eggs of Chinese Mitten crab (Eriocheir sinensis)- Laboratory Studies. International Research Journal of Biological Sciences, 2 (1): 1-6.

CZERNIEJEWSKI, P. \& W. WAWRZYNIAK. 2006. Seasonal changes in the population structure of the Chinese mitten crab, Eriocheir sinensis (H. Milne Edwards) in the Odra/Oder estuary. Crustaceana, 79 (10): 1167-1179. 10.1163/156854006778859588

DE LAFONTAINE, Y., J. M. SÉVIGNY, R. CALVÉ, G. VERREAULT, S. P. DESPATIE \& E. VEILLEUX. 2008. Chinese mitten crabs (Eriocheir sinensis) in the St. Lawrence River and Estuary, Canada: new records and risk of invasion. Aquatic invasions, 3 (2): 153-163. 10.3391/ai.2008.3.2.5

DIAS, A. A. \& J. M. S. MARQUES 1999. Estuários. Estuário do Tejo. O seu valor e um pouco da sua história. Reserva Natural do Estuário do Tejo, Instituto da Conservação da Natureza. Alcochete.

DITTEL, A. I. \& C. E. EPIFANIO. 2009. Invasion biology of the Chinese mitten crab Eriochier sinensis: A brief review. Journal of Experimental Marine Biology and Ecology, 374 (2): 79-92. 10.1016/j.jembe.2009.04.012

DROTZ, M., M. BERGGREN, S. LUNDBERG, K. LUNDIN \& T. VON PROSCHWITZ. 2010. Invasion routes, current and historical distribution of the Chinese mitten crab 
(Eriocheir sinensis H. Milne Edwards, 1853) in Sweden. Aquatic invasions, 5 (4). 10.3391/ai.2010.5.4.08

EU 2014. Regulation (EU) no $1143 / 2014$ of the european parliament and of the council of 22 October 2014 on the prevention and management of the introduction and spread of invasive alien species, Vol. 1143/2014, edited by E. Union, pp. 35-55. Official Journal of the European Union.

FLADUNG, E. 2000. Untersuchungen zur Bestandsregulierung und Verwertung der chinesischen Wollhandkrabbe (Eriocheir sinensis): Unter besonderer Berücksichtigung der Fischereiverhältnisse im Elbe/Havel-Gebiet. Inst. für Binnenfischerei.

FRANZ, G., R. FEMANDES, J. DE PABLO, H., C. VIEGAS, L. PINTO, F. CAMPUZANO, I. ASCIONE, P. LEITÃO \& R. NEVES 2014. Tagus Estuary hydro-biogeochemical model: Inter-annual validation and operational model update, 3.as Jornadas de Engenharia Hidrografica, Lisbon, Portugal.

GARCIA-DE-LOMAS, J., E. DANA, J. LÓPEZ-SANTIAGO, R. GONZÁLEZ, G. CEBALLOS \& F. ORTEGA. 2010. Management of the Chinese mitten crab, Eriocheir sinensis (H. Milne Edwards, 1853) in the Guadalquivir Estuary (Southern Spain). Aquatic invasions, 5 (3). 10.3391/ai.2010.5. 3.11

HE, J., X. G. WU \& Y. X. CHENG. 2016. Effects of limb autotomy on growth, feeding and regeneration in the juvenile Eriocheir sinensis. Aquaculture, 457: 79-84. 10.1016/j.aquaculture. 2016.02.004

HERBORG, L.-M., D. A. RUDNICK, Y. SILIANG, D. M. LODGE \& H. J. MACISAAC. 2007a. Predicting the Range of Chinese Mitten Crabs in Europe. Conservation Biology, 21 (5): 1316-1323. 10.1111/j.15231739.2007.00778.x

HERBORG, L., D. WEETMAN, C. VAN OOSTERHOUT \& B. HÄNFLING. 2007b. Genetic population structure and contemporary dispersal patterns of a recent European invader, the Chinese mitten crab, Eriocheir sinensis. Molecular Ecology, 16 (2): 231-242. 10.1111/j.1365-294X.2006.03133.x
HYMANSON, Z., J. WANG \& T. SASAKI. 1999. Lessons from the home of the Chinese mitten crab. IEP Newsletter, 12 (3): 25-32.

JEONG, E.-C., C.-D. PARK, S.-W. PARK, J.-H. LEE \& T. TOKAI. 2000. Size selectivity of trap for male red queen crab Chionoecetes japonicus with the extended SELECT model. Fisheries Science, 66 (3): 494-501. 10.1046/ j.1444-2906.2000.00079.x

JIN, G., Z. LI \& P. XIE. 2001. The Growth Patterns of Juvenile and Precocious Chinese Mitten Crabs, Eriocheir sinensis (Decapoda, Grapsidae), Stocked in Freshwater Lakes of China. Crustaceana, 74 (3): 261-273.

JIN, G., P. XIE \& Z. LI. 2002. The Precocious Chinese Mitten Crab: Changes of Gonad, Survival Rate, and Life Span in a Freshwater Lake. Journal of Crustacean Biology, 22 (2): 411-415.

JUANES, F. \& L. D. SMITH. 1995. The ecological consequences of limb damage and loss in decapod crustaceans: a review and prospectus. Journal of Experimental Marine Biology and Ecology, 193 (1-2): 197-223. http://doi.org/10. 1016/0022-0981(95)00118-2

KAMPS, L. F. 1937. De chineesche wolhandkrab in Nederland. F. Ozinga" De Marne".

LOWE, S., M. BROWNE, S. BOUDJELAS \& M. DE POORTER 2000. 100 of the world's most invasive alien species. A selection from the global invasive species database. Invasive Species Specialist Group (ISSG) of the IUCN.

MARIAPPAN, P., C. BALASUNDARAM \& B. SCHMITZ. 2000. Decapod crustacean chelipeds: an overview. Journal of biosciences, 25 (3): 301-313.

MONTÚ, M., K. ANGER \& C. DE BAKKER. 1996. Larval development of the Chinese mitten crab Eriocheir sinensis H. Milne-Edwards (Decapoda: Grapsidae) reared in the laboratory. Helgoland Marine Research, 50 (2): 223-252.

MORRITT, D., H. MILLS, K. HIND, D. CLIFTON-DEY \& P. F. CLARK. 2013. Monitoring downstream migrations of Eriocheir sinensis H. Milne Edwards, 1853 (Crustacea: Brachyura: Grapsoidea: Varunidae) in the River Thames using capture data from a water 
abstraction intake. Management of Biological Invasions, 4 (2): 139-147. http://doi.org/10. 3391/mbi.2013.4.2.07

MUNRO, J. 1982. Estimation of the parameters of the von Bertalanffy growth equation from recapture data at variable time intervals. Journal du Conseil, 40 (2): 199-200.

OJAVEER, H., S. GOLLASCH, A. JAANUS, J. KOTTA, A. LAINE, A. MINDE, M. NORMANT \& V. PANOV. 2007. Chinese mitten crab Eriocheir sinensis in the Baltic Sea-a supply-side invader? Biological Invasions, 9 (4): 409-418. 10.1007/s10530-0069047-z

OTTO, T. \& D. BRANDIS. 2011. First evidence of Eriocheir sinensis reproduction from Schleswig-Holstein, northern Germany, western Baltic Sea. Aquatic invasions, 6 (1): S65-S69. 10.3391/ai.2011.6.S1.015

PANNING, A. 1938. The Chinese mitten crab. Smithsonian Annual Report.

PETERS, N. 1933. Die chinesische Wollhandkrabbe (Eriocheir sinensis H. Milne-Edwards) in Deutschland. Zoologischer Anzeiger, 104: 59-155.

PEZY, J.-P., J.-C. DAUVIN \& T. VINCENT. 2015. New records of Eriocheir sinensis H. Milne Edwards, 1853 in Normandy. Marine Biodiversity Records, 8: e15. 10.1017/S17552 67214001389

RICKER, W. E. 1975. Computation and interpertation of biological statistics of fish populations. Bulletin of the Fisheries Research Board of Canada, 191: 1-382.

ROBBINS, R. S., M. SAKARI, S. N. BALUCHI \& P. F. CLARK. 2006. The occurrence of Eriocheir sinensis H. Milne Edwards, 1853 (Crustacea: Brachyura: Varunidae) from the Caspian Sea region, Iran. Aquatic invasions, 1 (1): 32-34.

RUDEK, J., H. W. PAERL, M. A. MALLIN \& P. W. BATES. 1991. Seasonal and hydrological control of phytoplankton nutrient limitation in the lower Neuse River Estuary, North Carolina. Marine ecology progress series. Oldendorf, 75 (2): 133-142.

RUDNICK, D., K. M. HALAT \& V. H. RESH. 2000. Distribution, Ecology and Potential Impacts of the Chinese Mitten Crab
(Eriocheir sinensis) in San Francisco Bay. University of California, Water Resources Center, Berkeley.

RUDNICK, D., T. VELDHUIZEN, R. TULLIS, C. CULVER, K. HIEB \& B. TSUKIMURA. 2005. A life history model for the San Francisco Estuary population of the Chinese mitten crab, Eriocheir sinensis (Decapoda: Grapsoidea). Biological Invasions, 7 (2): 333-350. 10.1007/s10530-004-2286-y

RUDNICK, D. A., K. HIEB, K. F. GRIMMER \& V. H. RESH. 2003. Patterns and processes of biological invasion: The Chinese mitten crab in San Francisco Bay. Basic and Applied Ecology, 4: 249-262.

SCHÄFERNA, K. 1935. About the Chinese mitten crab. Ryb. vest, 15 (8): 117-121.

SNIRH 2015. Sistema Nacional de Informação de Recursos Hídricos, http://snirh.apambiente.pt

SPARRE, P., E. URSIN \& S. C. VENEMA. 1992. Introduction to tropical fish stock assessment. Part 1 - Manual. FAO Rome

SUI, L., M. WILLE, Y. CHENG, X. WU \& P. SORGELOOS. 2011. Larviculture techniques of Chinese mitten crab Eriocheir sinensis. Aquaculture, 315 (1-2): 16-19. http://doi.org/10.1016/j.aquaculture.2010.06. 021

VEILLEUX, É. \& Y. DE LAFONTAINE. 2007. Biological synopsis of the Chinese mitten crab (Eriocheir sinensis). Fisheries and Oceans Canada, Science Branch, Pacific Region, Pacific Biological Station,

WÓJCIK, D. \& M. NORMANT. 2014. Gonad maturity in female Chinese mitten crab Eriocheir sinensis from the southern Baltic Sea - the first description of ovigerous females and the embryo developmental stage. Oceanologia, 56 (4): 779-787. 10.5697/oc.56-4.779

WÓJCIK, D., A. WOJTCZAK, P. ANASTÁCIO $\&$ M. NORMANT. 2014. The highly invasive Chinese mitten crab Eriocheir sinensis in the Tagus Estuary, Portugal: morphology of the specimens 20 years after the first captures. Annales de Limnologie - International Journal of Limnology, 50 (3): 249-251. 10.1051/ $\operatorname{limn} / 2014019$

ZHANG, T. L., Z. J. LI \& Y. B. CUI. 2001. Survival, growth, sex ratio, and maturity of 
the Chinese mitten crab (Eriocheir sinensis) reared in a Chinese pond. Journal of Freshwa- ter Ecology, 16 (4): 633-640. 10.1080/02705060. 2001.9663855 